\title{
Initial development of Physalis seedlings in substrates and containers
}

\author{
Fabíola Villa ${ }^{*}$, Daniel Fernandes da Silva², Thiago Augusto Peron', Éder Junior Mezzalira'
}

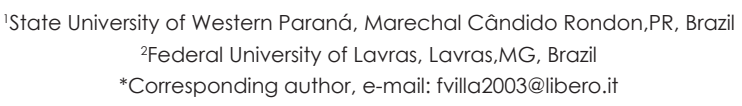

\begin{abstract}
The objective of this study was to evaluate the growth of Physalis peruviana and Physalis pubescens in containers and substrates, as well as the growth of transplanted P. pubescens seedlings into different containers and substrates. It was used for transplanting experiment (El) plastic bags, disposable plastic glasses and plastic tubes containing four substrates: oxisol; commercial substrate; commercial substrate + fine washed sand; and commercial substrate + oxisol + fine washed sand. For the experiment of containers $x$ substrates (E2) it was used polystyrene and polypropylene trays, both with 200 cells containing two substrates: vermiculite + commercial substrate and vermiculite + oxisol. For the experiment of containers $x$ substrates (E3), it was used polystyrene trays with 128 and 200 cells and plastic tubes containing four substrates: commercial substrate, oxisol, fine washed sand, oxisol + fine washed sand and oxisol + fine washed sand + commercial substrate. The experimental design used in E1, E2 and E3 was randomized blocks in factorial $3 \times 4,2 \times 2$, and $3 \times 5$, respectively, containing 4 replicates and 10 plants per plot. The use of commercial substrate Húmus Fértil ${ }^{\circledR}$ for $P$. pubescens seedlings transplanted from seedbed to containers such as plastic glasses or plastic bags provides better seedling growth. For Physalis peruviana, better results are verified in the use of polypropylene tubes containing washed fine sand + commercial substrate Húmus Fértil ${ }^{\circledR}+$ oxisol or washed fine sand + oxisol. Better results for formation of $P$. pubescens seedlings were verified by using expanded polystyrene trays containing oxisol + vermiculite mixture.
\end{abstract}

Keywords: initial growth, Physalis peruviana L., Physalis pubescens L., sexual propagation Introduction

Physalis is one of the most easily recognized genera among solanaceae, due to its very peculiar characteristics such as intense yellow-gold fruit and a conical chalice involving the fruit in more than one hundred species of this genus (Fischer et al., 2014). Among these species, some have detached for their beneficial properties to human health and commercial activities.

Little is known about the growing techniques of these species for commercial purposes, since they grow naturally in South America. Among these species, the most grown in Colombia and South Africa are Physalis peruviana and $P$. pubescens, due to their better fruit quality. In Brazil, the cultivation of this fruit is still incipient, being consumed as an exotic fruit (non-conventional fruit) with high market prices (Muniz et al., 2014).

One of the important steps to obtain a well-structured orchard that produces high quality fruits is the seedling formation phase. For the success of an orchard, the seedling production with technology that has good sanitary and genetic quality is crucial. The most commonly used and most common way of propagating physalis is by seeds (Rufato et al., 2008; Silva et al., 2016). 
For seedlings formation, sowing can be performed in a protected environment, using containers, together with substrate of good origin and with desirable physicochemical characteristics, such as low density, high porosity and water retention capacity, free of pathogens, adequate concentrations of macro and micronutrients, among others (Pereira et al., 2010). All these characteristics are difficult to find in only one substrate, making it necessary to mix in order to achieve a substrate closer to the desired (Kämpf, 2000).

One factor that directly affects the final seedling production cost is the size of the container used (Zaccheo et al., 2013). The plastic bag was once the most used container for the seedling production of fruit trees in Brazil, but it has the disadvantage of provoking excessive rooting, which decreased plant growth. As a consequence of this, new containers have been used for seedling production, such as polypropylene and polystyrene trays, recyclable containers and tubes. In some cases, sowing can be done in sowing and transplantation is necessary for larger containers after seed germination and seedling emergence (Rufato et al., 2008).

In this sense, the objective of this work was to evaluate the growth of Physalis peruviana and Physalis pubescens grown in different containers and substrates; and the seedling development of $P$. pubescens, transplanted from sand bed to containers.

\section{Material and Methods}

The experiments were carried out at the Universidade Estadual do Oeste do Paraná (Unioeste), Campus Marechal Cândido Rondon, using two physalis species (Physalis peruviana and $P$. pubescens), collected at different sites.

The experiments of transplanted seedlings

(E1) of Physalis pubescens seeds and containers $x$ substrates (E2 and E3) were conducted in the nursery of seedlings of the Center of Agricultural Sciences (CCA) of the Universidade Estadual do Oeste do Paraná (Unioeste). P. pubescens seeds were obtained from mature fruits (intense yellow color and open chalice), of one year old plants, located in the UTFPR of Pato Branco, Paraná,
Brazil. P. peruviana seeds were obtained from mature fruits, from one year old planting, located at the Experimental Farm of the Agricultural Research Company of Minas Gerais (EPAMIG), located in Maria da Fé, Minas Gerais, Brazil. The fruits were manually harvestedand the seeds were removed using a sieve and running water, and then shade dried. After drying during 15 days, the seeds were used in the experiments, following th methodology of Silva et al. (2013).

For El, one thousand $P$. pubescens seeds were sown in a germination bed $0.60 \mathrm{~m}$ wide $\mathrm{x}$ $6 \mathrm{~m}$ long $\times 0.40 \mathrm{~m}$ high), containing fine washed and sterilized sand. After 30 days, $5 \mathrm{~cm}$ seedlings with a well-developed root system were selected for transplantation in appropriate treatments (containers and substrates). Black plastic bags $(10 \mathrm{~cm}$ in diameter $\times 18 \mathrm{~cm}$ in height $\times 0.06 \mathrm{~cm}$ in thickness), plastic glasses (500 $\mathrm{ml}$ ) and black polypropylene tubes $(4.5 \mathrm{~cm}$ in diameter $\times 14 \mathrm{~cm}$ of length) were used as containers and filled with the four substrates (latosol, commercial substrate Húmus Fértil ${ }^{\circledR}$, commercial substrate Húmus Fértil ${ }^{\circledR}$ + fine sand washed, in the ratio $2: 1 \mathrm{v} / \mathrm{v}$ and Humus Ferti ${ }^{\circledR}+$ Oxisol soil + fine washed sand, in proportion 2:1:1 v/v/v).

For E2, the recipients used were 200cell expanded polystyrene trays and 200-cell polypropylene trays containing two substrates (fine granulometry vermiculite + commercial substrate Húmus Férti ${ }^{\circledR}$ and vermiculite + latosol in a 1:1 v/v ratio). P. pubescens species was studied in this experiment.

For E3, Physalis peruviana seeds were sowed in 200-cell expanded polystyrene trays, 128-cell expanded polystyrene tray and 120 $\mathrm{cm}^{3}$ black polypropylene tubes filled with five substrates (commercial substrate Húmus Fértil ${ }^{\circledR}$, oxisol, washed fine sand, oxisol + fine washed sand at 1:1 ( $/ \mathrm{v} / \mathrm{v})$ proportion and oxisol + fine washed sand + Húmus Fértil ${ }^{\circledR}$ commercial substrate, in a ratio of 2:1:1 (v/v/v).

The containers + substrates (E2 and E3) were placed on a metal bed, in a canvassed shelter under shade conditions (50\% shading). Irrigation was performed daily and manually and the cultural treatments were performed according to the general indication for production of solanaceous seedlings. Hand weeding was 
also performed to avoid competition with the desired plants.

After 70 days of experimentation, fresh biomass of aerial part and roots (g) were evaluated in El. After weighing, they were placed in brown kraft paper bags previously identified with the treatments and placed in an oven at $60^{\circ} \mathrm{C}$ for one week until the fresh biomass stabilization. After this time, the plant material was removed and weighed again, to verify the dry biomass (g). For E2 and E3, the number of leaves, plant length (cm), using a ruler, and stem diameter $(\mathrm{mm})$ were evaluated after 70 days, using a digital paquimeter.

The experimental design used in El, E2 and $\mathrm{E} 3$ was randomized blocks, factorial scheme $3 \times 4$ (containers $\times$ substrates), $2 \times 2$ (containers $x$ substrates), and $3 \times 5$ (containers $x$ substrates), respectively, containing 4 replicates and 10 plants per replicate. The data were submitted to variance analysis using SISVAR software (Ferreira, 2011), and the means were compared by the Scott-Knott test, at $5 \%$ probability of error.

\section{Results and Discussion}

\section{El Experiment}

Significant interaction was observed for shoot length, stem diameter, and fresh and dry shoot biomass, in addition to isolated significance for substrates and containers for number of leaves. In Table 1, better results can be verified for number of leaves with the use of black bag and commercial substrate Húmus Fértil ${ }^{\circledR}$.
The worse results in seedling transplantation were observed for the tubes, with smaller seedlings and few leaves. The poor development of fruit tree seedlings in tubes may be mainly related to the substrate, whose nutrients limit and/or depleted in a short time (Costa et al., 2011 ), since fruit plants need a longer period for growth in relation to horticultural plants.

The negative results recorded for the physalis seedlings transplantation to the tubes in relation to the other containers can be attributed to the substrate volume. Although the tubes have a satisfactory structure for root system growth, the substrate volume may not be sufficient for an adequate nutrition of physalis plants during the seedling formation phase, being verified the best result for black polyethylene bags that contained a larger substrate volume, followed by plastic glasses which had an intermediate substrate volume. This way, a plausible alternative for physalis seedling production in tubes can be the use of larger tubes.

The use of plastic bags is advantageous because it is easy to acquire, low cost and it has a greater area for root development. However, for physalis seedlings, in which the root system develops rapidly and produces a large root volume, attention should be paid to the possible folding, a factor that may impair the seedling development after field transplantation. The same can occur for plastic glasses. These factors must be considered for recipient chose (Francisco et al., 2010).

Table 1. Number of leaves in physalis seedling grown in recipients filled with substrates.

\begin{tabular}{lc}
\hline Substrates & Number of leaves \\
\hline$C S^{(2)}+F W S^{(1)}$ & $4.667 \mathrm{~b} *$ \\
$F W S^{(1)}+C S^{(2)}+O X^{(3)}$ & $5.611 \mathrm{~b}$ \\
$O X^{(3)}$ & $4.241 \mathrm{~b}$ \\
$C S^{(2)}$ & $7.278 \mathrm{a}$ \\
\hline $\mathrm{CV}(\%)$ & 11.92 \\
\hline Recipient & Number of leaves \\
\hline Tube & $3.250 \mathrm{C}$ \\
Plastic glass & $5.389 \mathrm{~b}$ \\
Black polyethilene bag & $7.708 \mathrm{a}$ \\
\hline CV(\%) & 8.47 \\
\hline "Averages values followed by the same small letter in column show no statistical difference by Scott-Knott test at 5\% probability error.
\end{tabular}

$\mathrm{CV}=$ Coefficient of variation. $\mathrm{FWS}(1)$ = fine washed sand; $\mathrm{CS}(2)$ = commercial substrate Húmus Fértil(®; $\mathrm{OX}(3)=$ oxisol.

The commercial substrate promotes high moisture percentage and a $\mathrm{pH}$ value of 6.8 (Pelizza et al., 2011). According to Rufato et al. (2008), substrates indicated for physalis seedling production are those that present a granular structure and preferably $\mathrm{pH}$ values around 5.5 and 6.8, as observed in commercial substrates used in this study. Piva et al. (2013) also observed 
better results for seedling emergence of $P$. peruviana in tubes containing vermiculite-based mixtures.

A significant interaction was observed for the average shoot length of physalis seedlings (Table 2), with significant results observed with the use of plastic bags and plastic glasses, added with commercial substrate, corroborating with Cardoso et al. (2001), who obtained similar results with the use of disposable glasses for yellow passion fruit seedling production.

Table 2. Shoot length $(\mathrm{cm})$ and stem diameter $(\mathrm{mm})$ of physalis seedlings grown in recipients filled with substrates.

\begin{tabular}{|c|c|c|c|c|}
\hline \multirow[b]{3}{*}{ Recipient } & \multicolumn{4}{|c|}{ Shoot length (cm) } \\
\hline & \multicolumn{4}{|c|}{ Substrates } \\
\hline & $\mathrm{CS}^{(2)}+\mathrm{AFL}^{(1)}$ & $\mathrm{AFL}^{(1)}+\mathrm{SCFH}^{(2)}+\mathrm{OX}$ & $O X^{(3)}$ & $\mathrm{CS}^{(2)}$ \\
\hline Tube & $8.017 a^{*}$ & $5.850 \mathrm{aB}$ & $1.817 \mathrm{bB}$ & $9.750 \mathrm{aB}$ \\
\hline Plastic glass & $10.850 \mathrm{a}$ & $10.773 \mathrm{bA}$ & $11.743 \mathrm{bA}$ & $20.340 \mathrm{aA}$ \\
\hline \multirow[t]{3}{*}{ Black polyethilene bag } & $10.800 \mathrm{~b}$ & $11.327 \mathrm{bA}$ & $11.533 \mathrm{bA}$ & $23.500 \mathrm{aA}$ \\
\hline & \multicolumn{4}{|c|}{ Average stem diameter (mm) } \\
\hline & $\mathrm{CS}^{(2)}+\mathrm{AFL}^{(1)}$ & $\mathrm{AFL}^{(1)}+\mathrm{CS}^{(2)}+\mathrm{OX}$ & $O X^{(3)}$ & $\mathrm{CS}^{(2)}$ \\
\hline Tube & $1.815 \mathrm{~b}$ & $1.428 \mathrm{bB}$ & $0.403 \mathrm{cB}$ & $2.217 \mathrm{aC}$ \\
\hline Plastic glass & $2.315 b$ & $2.172 \mathrm{bA}$ & $2.042 \mathrm{bA}$ & $3.718 \mathrm{aA}$ \\
\hline Black polyethilene bag & $2.367 \mathrm{~b}$ & $2.097 \mathrm{bA}$ & $2.278 \mathrm{bA}$ & $3.145 \mathrm{aB}$ \\
\hline
\end{tabular}

${ }^{*}$ Averages values followed by the same small letter in column and capital letter in row show no statistical difference by Scott-Knott test at $5 \%$ probability error. $\mathrm{CV}=$ Coefficient of variation. $\mathrm{FWS}(1)$ = fine washed sand; $\mathrm{CS}(2)$ = commercial substrate Húmus Fértil(ब; OX(3) = oxisol.

The use of these containers promotes better root development and greater initial survival of fruit trees due to their larger size. These types of containers are a good option for small nurseries, due to the easier availability and more affordable price, associated to the substrates or ideal mixtures for the fruit trees. The use of commercial substrates for seedling preparation may provide necessary amounts of organic matter, providing better seedling development (Rodrigues et al., 2010).

The worst results for shoot length were observed for soil use as a substrate. This is probably because it does not have an adequate humidity/aeration balance, nor good drainage capacity, from a layer of oxisol. Beyond the soil is a low-cost substrate with variable composition, it presents easy compactation and high moisture retention, factors that compromises the seedling development of fruit species (Ferraz et al., 2002).

Is observes in Table 2 the significant interaction for the stem diameter of physalis seedlings, with satisfactory results for the use of plastic glasses + commercial substrate, verifying a balance between stem diameter and shoot length height. Once again unsatisfactory results were observed for the tube as a container for seedling formation. The smaller stem diameter found for the combination of tube and soil was possibly due to the lower nutrient availability in a smaller soil volume, aggravated by the absence of organic and mineral sources, and also by the low nutrient levels available in the soil used as substrate.

It is possible to observe in Table 3 the significant interaction between the container type and the substrate used, being better results for fresh and dry biomass verified for seedling formation in tubes filled with Humus Fértil ${ }^{\circledR}$.

The increase in seedling fresh biomass probably occurred due to the greater branching capacity of the plants in this substrate, during the seedling formation. In addition, the physical structure of the commercial substrate may allow greater root exploration within the tube and better development of the whole seedling (Fachinello et al., 2005).

Table 4 shows the average of substrates and containers for fresh root biomass and the significant interaction for root dry biomass.

\section{Experiment E2}

It was recorded significant effect for the average steam diameter colon and average shoot length of physalis seedlings, as a function of substrates and containers separately (Table 5).

Better results for average shoot length were recorded for seedling grown with the OX + FGV mix, independently of the container used, since both have the same number and size of cells. 
Table 3. Dry and fresh shoot mass (mg) of physalis seedlings grown in recipients filled with substrates.

\begin{tabular}{|c|c|c|c|c|}
\hline \multirow[b]{3}{*}{ Recipient } & \multicolumn{4}{|c|}{ Shoot fresh mass (mg) } \\
\hline & \multicolumn{4}{|c|}{ Substrates } \\
\hline & $\mathrm{SCFH}^{(2)}+\mathrm{FWS}^{(1)}$ & $F W S^{(1)}+C S^{(2)}+O X^{(3)}$ & $O X^{(3)}$ & $\mathrm{CS}^{(2)}$ \\
\hline Tube & $1.664 \mathrm{bA}^{*}$ & $1.706 \mathrm{bA}$ & $1.541 \mathrm{bA}$ & $2.743 \mathrm{aA}$ \\
\hline Plastic glass & $1.508 \mathrm{aA}$ & $1.410 \mathrm{bB}$ & $1.540 \mathrm{bA}$ & $2.256 \mathrm{aB}$ \\
\hline \multirow[t]{3}{*}{ Black polyethilene bag } & $1.019 \mathrm{aB}$ & $0.806 \mathrm{bc}$ & $1.078 \mathrm{aB}$ & $1.288 \mathrm{aC}$ \\
\hline & \multicolumn{4}{|c|}{ Shoot dry mass (mg) } \\
\hline & \multicolumn{4}{|c|}{ Substratos } \\
\hline Recipient & $\mathrm{CS}^{(2)}+\mathrm{FWS}^{(1)}$ & $F W S^{(1)}+C S^{(2)}+O X^{(3)}$ & $O X^{(3)}$ & $\mathrm{CS}^{(2)}$ \\
\hline Tube & $0.921 \mathrm{bA}$ & $0.894 \mathrm{bA}$ & $0.948 \mathrm{bA}$ & $1.317 \mathrm{aA}$ \\
\hline Plastic glass & $0.771 \mathrm{bB}$ & $0.726 \mathrm{bB}$ & $0.813 \mathrm{aB}$ & $0.863 \mathrm{aC}$ \\
\hline Black polyethilene bag & $0.903 \mathrm{bA}$ & $0.880 \mathrm{bA}$ & $0.964 \mathrm{bA}$ & $1.115 \mathrm{aB}$ \\
\hline
\end{tabular}

*Averages values followed by the same small letter in column and capital letter in row show no statistical difference by Scott-Knott test at 5\% probability error.

FWS (1) = fine washed sand; CS(2) = commercial substrate Húmus Fértißß; OX(3) = oxisol.

Table 4. Dry and fresh root mass (g) of physalis seedlings grown in recipients filled with substrates.

\begin{tabular}{|c|c|c|c|c|}
\hline \multicolumn{5}{|c|}{ Root fresh mass (g) } \\
\hline Substrates & & \multicolumn{3}{|c|}{ Average } \\
\hline$\overline{C S^{(2)}+F W S^{(1)}}$ & & \multicolumn{3}{|c|}{$1.527 b^{*}$} \\
\hline$F W S^{(1)}+C S^{(2)}+O X^{(3)}$ & & \multicolumn{3}{|c|}{$1.314 \mathrm{C}$} \\
\hline$O X^{(3)}$ & & \multicolumn{3}{|c|}{$1.635 \mathrm{~b}$} \\
\hline $\mathrm{CS}^{(2)}$ & & \multicolumn{3}{|c|}{$2.099 \mathrm{a}$} \\
\hline Recipients & & \multicolumn{3}{|c|}{ Average } \\
\hline Tube & & \multicolumn{3}{|c|}{$1.602 \mathrm{~b}$} \\
\hline Plastic glass & & \multicolumn{3}{|c|}{$2.073 a$} \\
\hline Black polyethilene bag & & \multicolumn{3}{|c|}{$1.257 \mathrm{C}$} \\
\hline \multicolumn{5}{|c|}{ Root dry mass (g) } \\
\hline & \multicolumn{4}{|c|}{ Substrates } \\
\hline Recipients & $C S^{(2)}+F W S^{(1)}$ & $\mathrm{FWS}^{(1)}+\mathrm{CS}^{(2)}+\mathrm{OX}^{(3)}$ & $O X^{(3)}$ & $\mathrm{CS}^{(2)}$ \\
\hline Tube & $0.921 \mathrm{bA}$ & $0.894 \mathrm{bA}$ & $0.948 \mathrm{bA}$ & $1.317 \mathrm{aA}$ \\
\hline Plastic glass & $0.771 \mathrm{bB}$ & $0.726 \mathrm{bB}$ & $0.813 \mathrm{aB}$ & $0.863 \mathrm{ac}$ \\
\hline Black polyethilene bag & $0.903 \mathrm{bA}$ & $0.880 \mathrm{bA}$ & $0.964 \mathrm{bA}$ & $1.115 \mathrm{aB}$ \\
\hline
\end{tabular}

*Averages values followed by the same small letter in column and capital letter in row show no statistical difference by Scott-Knott test at 5\% probability error.

FWS (1) = fine washed sand; CS(2) = commercial substrate Húmus Fértil(B; OX(3) = oxisol.

Table 5. Average stem diameter $(\mathrm{mm})$ and shoot length of physalis seedlings grown in recipients filled with substrates.

\begin{tabular}{|c|c|}
\hline \multicolumn{2}{|c|}{ Stem diameter (mm) } \\
\hline Substrate & Average \\
\hline $\mathrm{CS}^{(1)}+F G V^{(2)}$ & n.s. \\
\hline $\mathrm{OX}^{(3)}+\mathrm{FGV}(2)$ & n.s. \\
\hline Recipient & Average \\
\hline Expanded polystyrene tray with 200 cells & $1.220 \mathrm{a}^{*}$ \\
\hline Polypropylene tray with 200 cells & $1.136 \mathrm{~b}$ \\
\hline \multicolumn{2}{|c|}{ Shoot length $(\mathrm{cm})$} \\
\hline Substrate & Average \\
\hline $\mathrm{CS}^{(1)}+\mathrm{FGV}(2)$ & $1.409 \mathrm{~b}$ \\
\hline $\mathrm{OX}^{(3)}+\mathrm{FGV}(2)$ & $1.667 \mathrm{a}$ \\
\hline Recipient & Average \\
\hline Expanded polystyrene tray with 200 cells & $1.659 \mathrm{a}$ \\
\hline Polypropylene tray with 200 cells & $1.418 \mathrm{a}$ \\
\hline
\end{tabular}

The most recommended soils for physalis must have a granular structure and preferably contain high organic matter content and $\mathrm{pH}$ between 5.5 and 6.8 (Rufato et al., 2008). The use of vermiculite in this mixture provided an improvement in the physical conditions of the substrate, promoting better cation exchange capacity (CEC), water retention, soil conditioner, $\mathrm{pH}$ correction, making the substrate more porous and aerated; promoting better seedling 
development and making easier to take off the seedling from the recipient (Ugarte et al., 2005).

For average diameter, satisfactory results were observed with the use of polystyrene trays. In practice, it is observed that in seedling production, there is predominance in tray use with smaller cell volumes, but with large amounts of them, as trays of 200 cells. These produce large amounts of seedlings, with less substrate expense.

In an experiment with passion fruit seedlings grown under similar edaphoclimatic conditions of west of Paraná, Costa et al. (2009) argued that the use of polystyrene trays had an advantage in seedling development, since the material (styrofoam) is a thermal insulation, allowing better root development under high temperature conditions.

\section{Experiment E3}

In Table 6 is verifies a significant interaction between substrates and containers for the number of leaves.

Table 6. Number of leaves of physalis seedlings grown in recipients filled with substrates.

\begin{tabular}{|c|c|c|c|}
\hline & \multicolumn{3}{|c|}{ Recipient } \\
\hline Substratos & EPT 128 & EPT 200 & Tube \\
\hline$\overline{F W S^{(1)}+C S^{(2)}+O X^{(3)}}$ & $1.954 \mathrm{aB}^{*}$ & $1.957 \mathrm{aB}$ & $2.542 \mathrm{aA}$ \\
\hline FWS $(1)$ & $0.707 \mathrm{CB}$ & $0.707 \mathrm{bB}$ & $1.989 \mathrm{bA}$ \\
\hline$F W S^{(1)}+O X^{(3)}$ & $1.387 \mathrm{bB}$ & $1.065 \mathrm{bB}$ & $2.313 \mathrm{aA}$ \\
\hline $\mathrm{CS}^{(2)}$ & $2.156 \mathrm{aA}$ & $1.575 \mathrm{aB}$ & $2.146 \mathrm{bA}$ \\
\hline$O X^{(3)}$ & $0.707 \mathrm{CB}$ & $0.707 \mathrm{bB}$ & $1.915 \mathrm{bA}$ \\
\hline
\end{tabular}

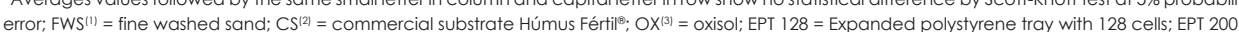
Expanded polystyrene tray with 200 cells.

It is possible to observe a greater number of leaves with the use of tubes and trays of 128 cells, containing sand + commercial substrate + oxisol, sand + oxisol and only commercial substrate.

Table 7 shows the significant interaction for the average shoot length and stem diameter of physalis seedlings. For the average shoot length, the substrate composed of by oxisol + fine washed sand + commercial Húmus Fértil ${ }^{\circledR}$ substrate mixture was superior in all three containers studied, matching only the commercial Húmus Fértil ${ }^{\circledR}$ substrate in 128 cell trays and oxisol + fine washed sand in tubes. This result demonstrates the demand for a good aeration of root system for a good seedling development. Also the substrate amount available for the seedling affects its development, which justifies higher values found for tubes for almost all substrates tested.

Table 7. Shoot length $(\mathrm{cm})$ and stem diameter $(\mathrm{mm})$ of physalis seedlings grown in recipients filled with substrates.

\begin{tabular}{|c|c|c|c|}
\hline \multicolumn{4}{|c|}{ Average shoot length (mm) } \\
\hline & \multicolumn{3}{|c|}{ Recipient } \\
\hline Substrate & BPE 128 & BPE & Tube \\
\hline $\mathrm{FWS}^{(1)}+\mathrm{CS}^{(2)}+\mathrm{OX}^{(3)}$ & $1.581 \mathrm{aA}^{*}$ & $1.567 \mathrm{aA}$ & $1.802 \mathrm{aA}$ \\
\hline FWS $(1)$ & $0.707 \mathrm{cB}$ & $0.707 \mathrm{cB}$ & $1.251 \mathrm{bA}$ \\
\hline$F W S^{(1)}+O X^{(3)}$ & $1.031 \mathrm{bB}$ & $0.919 \mathrm{cB}$ & $1.852 \mathrm{aA}$ \\
\hline $\mathrm{CS}^{(2)}$ & $1.536 \mathrm{aA}$ & $1.229 \mathrm{bB}$ & $1.761 \mathrm{bA}$ \\
\hline \multirow[t]{2}{*}{$O X^{(3)}$} & $0.707 \mathrm{cB}$ & $0.707 \mathrm{CB}$ & $1.699 \mathrm{bA}$ \\
\hline & \multicolumn{3}{|c|}{ Average stem diameter (mm) } \\
\hline $\mathrm{FWS}^{(1)}+\mathrm{CS}^{(2)}+O \mathrm{X}^{(3)}$ & $1.230 \mathrm{aB}$ & $1.247 \mathrm{aB}$ & $1.889 \mathrm{aA}$ \\
\hline FWS $(1)$ & $0.707 \mathrm{CB}$ & $0.707 \mathrm{bB}$ & $0.983 \mathrm{bA}$ \\
\hline$F W S^{(1)}+O X^{(3)}$ & $0.483 \mathrm{bB}$ & $0.283 \mathrm{bB}$ & $2.217 \mathrm{aA}$ \\
\hline $\operatorname{CS}^{(2)}$ & $1.361 \mathrm{aB}$ & $0.810 a C$ & $1.916 \mathrm{aA}$ \\
\hline$O X^{(3)}$ & $0.707 c B$ & $0.707 \mathrm{bB}$ & $1.416 \mathrm{bA}$ \\
\hline
\end{tabular}

FWS (1) = fine washed sand; CS(2) = commercial substrate Húmus Fértil(B; OX(3) = oxisol; EPT 128 = Expanded polystyrene tray with 128 cells; EPT $200=$ Exp anded polystyrene tray with 200 cells.

For average stem diameter, better results were observed in seedlings grown in tubes containing the substrates studied. In addition to the larger volume of substrate contained in the tubes, they have internal lateral friezes, and this vessel directs the lateral roots to better structure 
the root system (Bortolini et al., 2012).

The ratio between stem diameter and shoot length is one of the most important morphological characteristics to estimate the seedling growth after the final planting in the field. It expresses the growth equilibrium, relating these important morphological characteristics to only one index, also known as a robustness quotient, which is considered one of the most accurate and provides information on how thin is the seedling. Seedlings with low stem diameter, as verified in the seedlings grown in trays, present difficulties to remain erect after transplanting. The dumping off due to this characteristic can result in death or deformations that compromise the seedling value (Cunha et al., 2005).

The use of polystyrene and polyethylene trays is quite common in this technique because they have mobility in transportation and easy hygiene. However the tray cell size can directly affect the development and architecture of the root system, also affecting shoot development and seedling quality (Oliveira et al., 2011).

In a general evaluation of the parameters recorded of $P$. peruviana seedlings in the different containers and substrates studied, seedlings produced in tubes filled with washed fine sand + commercial substrate Húmus Fértil ${ }^{\circledR}+$ oxisol or washed fine sand + oxisol were superior.

\section{Conclusions}

The use of commercial substrate Húmus Fértil ${ }^{\circledR}$ for $P$. pubescens seedlings transplanted from seedbed to containers such as plastic glasses or plastic bags provides better seedling growth.

Better results for formation of $P$. pubescens seedlings were verified by using expanded polystyrene trays containing oxisol + vermiculite mixture.

For Physalis peruviana, better results are verified in the use of polypropylene tubes containing washed fine sand + commercial substrate Húmus Fértil ${ }^{\circledR}$ oxisol or washed fine sand + oxisol.

\section{References}

Bortolini, M.F., Soares, K.H., Zuffellato-Ribas, K.C., Fortes, A.M.T. 2012. Crescimento de mudas de Gleditschia amorphoides Taub. Produzidas em diferentes substratos. Ciência Florestal 22: 35-46.
Cardoso, G.D., Tavares, J.C., Ferreira, R.L.F., Câmara, F.A.A., Carmo, G.A. 2001. Desenvolvimento de mudas de maracujazeiroamarelo obtidas de sementes extraídas por fermentação. Revista Brasileira de Fruticultura 3: 639-642.

Costa, E., Santos, L.C.R., Vieira, L.C.R. 2009. Produção de mudas de mamoeiro utilizando diferentes substratos, ambientes de cultivo e recipientes. Engenharia Agrícola 29: 528-537.

Costa, E., Durante, L.G.Y., Nagel, P.L., Ferreira, C.R., Santos, A. 2011. Qualidade de mudas de berinjela submetida a diferentes métodos de produção. Revista Ciência Agronômica 42: 10171025.

Cunha, A.O., Andrade, L.A., Bruno, R.L.A., Algaci, J., Silva, L., Souza, V.C. 2005. Efeitos de substratos e das dimensões dos recipientes na qualidade das mudas de Tabebuia impetiginosa (Mart. Ex D.C.) Standl. Revista Árvore 29: 507-516.

Fachinello, J.C., Hoffmann, A., Nachtigal, J.C. 2005. Propagação de plantas frutíferas. Embrapa Informação Tecnológica, Brasília, Brasil. $221 \mathrm{p}$.

Ferraz, M.V., Centurion, J.F., Beutler, A.N. 2005. Caracterização física e química de alguns substratos comerciais. Acta scientiarum. Agronomy 27: 209-214.

Ferreira, D.F. 2011. SISVAR: a computer statistical analysis system. Ciência \& Agrotecnologia 35: 1039-1042.

Fischer, G., Almanza, M.P.J., Miranda, D. Importancia y cultivo de la uchuva (Physalis peruviana L.). 2014. Revista Brasileira de Fruticultura 36: 1-15.

Francisco, M.G.S., Maruyama, W.I., Mendonça, V., Silva, E.A., Reis, L.L., Leal, S.T. 2010. Substratos e recipientes na produção de mudas de mamoeiro 'Sunrise Solo'. Agrarian 3: 267-274.

Kämpf, A.N. 2000. Seleção de materiais para uso como substrato. In: Kämpf, A.N., Fermino, M.H. (Ed.). Substratos para plantas: a base da produção vegetal em recipientes. Gênesis, Porto Alegre, Brasil. p. 139-145.

Muniz, J., Kretzschmar, A.A., Rufato, L., Pelizza, T.R., Rufato, A.R., Macedo, T.A. 2014. Aspectos gerais da cultura da physalis. Ciência Rural 44:964-970.

Oliveira, G.H., Casaroli, D., Fagan, E.B., Silva, J.O., Soares, L.H., Sousa, M.C. 2011. Avaliação do crescimento de mudas de tomate em diferentes tipos de bandejas comerciais. Cerrado Agrociências 2: 84-90.

Pelizza, T.R., Damiani, C.R., Rufato, A.R., Affonso, 
L.B., Hawerroth, F.J., Schuch, M.W. 2011. Aclimatização e crescimento de plântulas de mirtileiro 'Clímax' micropropagadas em função do substrato e da cobertura plástica. Revista Brasileira de Fruticultura 33: 898-905.

Pereira, P.C., Melo, B., Freitas, R.S., Tomaz, M.A. Teixeira, I.R. 2010. Tamanho de recipientes e tipos de substrato na qualidade de mudas de tamarindeiro. Revista Verde de Agroecologia e Desenvolvimento Sustentável 5: 136-142.

Piva, A.L., Mezzalira, E.J., Santin, A., Schwantes, D., Klein, J., Rampim, L., Villa, F., Tsutsumi, C.Y., Nava, G.A. 2013. Emergence and initial development of Cape gooseberry (Physalis peruviana) seedlings with different substrate compositions. African Journal of Agricultural Research 8: 6579-6584.

Rodrigues, E.T., Leal, P.A.M., Costa, E., Paula, T.S., Gomes, V.A. 2010. Produção de mudas de tomateiro em diferentes substratos e recipientes em ambiente protegido. Horticultura Brasileira 28: 483-488.

Rufato, L., Rufato, A.R., Schelemper, C., Lima, C.S.M., Kretzschmar, A.A. 2008. Aspectos técnicos da cultura da Physalis. UDESC/UFPel, Lages/ Pelotas, Brasi. 100 p.

Silva, D.F.S., Villa, F., Barp, F.K., Rotili, M.C.C., Stumm, D.R. 2013. Conservação pós-colheita de fisális e desempenho produtivo em condições edafoclimáticas de Minas Gerais. Revista Ceres 60: 826-832.

Silva, D.F., Pio, R. Soares, J.D.R., Nogueira, P.V., Peche, P.M., Villa, F. 2016. The production of Physalis spp. seedlings grown under differentcolored shade nets. Acta Scientiarum Agronomy 38:257-263.

Ugarte, J.F.O., Sampaio, J.A., França, S.C.A. 2005. Vermiculita. In: Luz, A.B.; Lins, F.A.F. Rochas \& Minerais Industriais. CETEM/MCT, Rio de Janeiro, Brasil. p. 677-698.

Zaccheo, P.V.C., Aguiar, R.S., Stenzel, N.M.C., Neves, C.S.V.J. 2013. Tamanho de recipientes e tempo de formação de mudas no desenvolvimento e produção de maracujazeiroamarelo. Revista Brasileira de Fruticultura 35: 603607. 